\title{
PENGARUH PERAN PROJECT MANAGEMENT OFFICE (PMO) TERHADAP KINERJA PROYEK INFRASTRUKTUR KETENAGALISTIRKAN
}

\author{
Tonny Rizkya Nur Sasongko \\ Magister Manajemen Teknologi ITS, Surabaya \\ tonnysasongko@gmail.com \\ Bambang Syairuddin \\ Magister Manajemen Teknologi ITS, Surabaya \\ bambangsy@yahoo.com
}

\begin{abstract}
Project Management Office (PMO) is a tool used to control the projects conducted at PT. PLN. In general, the PMO factors in a project will have a positive effect on project performance. This study aims to determine the most influential $P M O$ factors in the implementation of PMO on the performance of the existing projects in PT. PLN. The research population was 54 project coordinators and administrative officers of the PMO system with the final sample consisted of 43 respondents. Classification and interrelationship between roles will be analyzed using factor analysis method. The results showed that the main factors influencing the implementation of PMO on the performance of electricity infrastructure projects were the factors of process, standard, methodology, human resource, and facility.
\end{abstract}

Keywords: PMO, Project Performance, Electricity Infrastructure, Factor Analysis.

\begin{abstract}
Abstrak: Project Management Office (PMO) digunakan sebagai alat (tool) untuk mengontrol proyek-proyek yang ada di PT PLN. Secara umum, faktor-faktor PMO pada suatu proyek akan berpengaruh positif terhadap kinerja proyek. Penelitian ini bertujuan untuk menganalisis faktor - faktor PMO yang paling berpengaruh dalam implementasi PMO terhadap kinerja proyek yang ada di PT PLN. Populasi penelitian adalah 54 koordinator proyek dan petugas administrasi sistem PMO, dengan sampel berjumlah 43 responden. Klasifikasi dan keterkaitan antar peran akan dianalisis dengan menggunakan metode analisis faktor. Hasil penelitian menunjukkan bahwa faktor-faktor yang berpengaruh pada implementasi PMO terhadap kinerja proyek infrastruktur ketenagalistrikan adalah faktor proses, standar, metodologi, sumber daya manusia (SDM) dan sarana.
\end{abstract}

Kata Kunci: PMO, Kinerja Proyek, Infrastruktur Ketenagalistrikan, Analisis Faktor.

\section{Pendahuluan}

Seiring meningkatnya pertumbuhan penduduk di Indonesia, maka kebutuhan listrik meningkat setiap tahunnya. Jumlah energi listrik terjual pada tahun 2014 sebesar 198.601,78 GWh meningkat 5.90\% dibandingkan tahun sebelumnya. Untuk menjawab kebutuhan tersebut, PLN terus berusaha untuk membangun infrastrukutur ketenagalistikan. Kondisi rencana pembangunan di PLN yang begitu banyak tanpa diimbangi oleh manajamen proyek yang baik dapat menyebabkan proses pembangunan infrastruktur menjadi terkendala dan beberapa proyek menjadi mangkrak. 
PLN telah mengambil langkah proaktif dan strategis untuk meningkatkan pengelolaan proyek - proyek infrastruktur ketenagalistrikan dengan membangun sebuah organisasi PMO (Project Management Office). Dibuatnya organisasi PMO bertujuan untuk dapat melihat jelas kendala proyek - proyek PLN dan mengetahui penyebabnya serta menjembatani pelaksanaan proyek dengan para direksi perusahaan agar dapat berkomunikasi dan memberikan masukan atas kesulitan yang di hadapi dilapangan (Sebayang, 2012).

Secara umum, faktor - faktor PMO pada suatu proyek akan berpengaruh positif terhadap kinerja proyek (Perdana, 2013). Secara kuantiatif PMO dapat berpengaruh terhadap kinerja proyek dan menjadikan pengiriman proyek termasuk pada salah satu parameternya (Wells, 2004). Selain itu, pada referensi lainnya juga menyebutkan PMO menjadikan kinerja proyek lebih efektif (Crawford, 2001).

Project management office (PMO) didefinisikan sebuah bentuk organisasi yang ditugaskan dengan tanggung jawab terkait dengan manajemen terpusat dan terkoordinasi atas semua proyek yang berada dilingkupnya (Institute, 2013). PMO mengendalikan manajemen dari berbagai proyek, program ataupun keduanya dikombinasi. PMO berkonsentrasi pada kegiatan koordinasi perencanaan, pembuatan prioritas dan pelaksanaan proyek yang berkenaan dengan organisasi diatasnya.

Penelitian yang dilakukan oleh Anderson et al (2007) PMO memiliki enam fungsi atau tanggung jawab yang berdasarkan benchmark kepada perusahaan memiliki rekam jejak manajemen proyek yang bagus, enam fungsi tersebut antara lain mengelola metodologi dan proses bersama, training dan pengembangan kompetensi, memberikan dukungan untuk proyek, berprilaku sebagai konsultan pada saat dibutuhkan, berkontribusi dengan memberikan rekomendasi terhadap pemilihan proyek, berkontribusi dengan memberikan rekomendasi terhdap jaminan kualitas proyek dan memberikan support kepada pemilik proyek.

Pada penelitian ini faktor - faktor PMO yang akan digunakan sekaligus menjadi referensi variabel mengacu pada Crawford (2001) antara lain: proses, standard dan metodologi, manajer proyek, training, project support, software tools, monitoring dan coaching (Simanjuntak,2005) mengemukakan kinerja adalah tingkat pencapaian hasil dalam rangka mewujudkan tujuan perusahaan. Tujuan dari penelitian ini memberikan gambaran mengenai faktor - faktor PMO manakah yang berpengaruh terhadap kinerja proyek infrastruktur ketenagalistrikan. 


\section{Metodologi}

Berdasarkan tujuan dari penelitian ini, yakni mencari faktor yang mempengaruhi kurangnya efektifitas penerapan PMO pada PT.PLN Persero, dalam hal ini metode yang digunakan adalah faktor analisis, untuk klasifikasi variabel yang dimasukan pada faktor analisis penulis mengadaptasi faktor - faktor yang sudah dilakukan peneltian sebelumnya oleh Kuen (2009). Penelitian akan menggunakan kuesioner sebagai media pengumpulan data dan menggunakan program bantu untuk kalkulasi statistik. Penelitian dipaparkan secara deskriptif serta menggunakan skala likert dengan skor 1 sampai 4 untuk menggukur pernyataan dari sangat tidak setuju hingga sangat setuju.

Tujuan dari penggunaan faktor analisis dari penelitian ini adalah mereduksi sejumlah variabel asal yang jumlahnya banyak menjadi variabel baru yang jumlahnya sedikit yang lebih laten terkait dengan membangunan proyek infrastruktur pada PT. PLN persero, mengidentifikasi adanya hubungan atau korelasi antar variabel penyusun dengan menguji koefisien korelasi antar faktor dengan komponen pembentuknya.

Secara garis besar dapat diuraikan sebagai berikut:

1. Identifikasi Masalah

Hal ini ditujukan untuk mencari keluaran masalah-masalah yang dihadapi saat dilakukannya investasi PMO pada tahun 2013 Hingga saat ini. Kendala tersebut diklasifikasi menjadi faktor-faktor yang menyebabkan tidak berjalannya PMO dengan efektif dan efisien.

\section{Analisis Penggunaan PMO}

Masukan dari analisa ini adalah dari daftar permasalahan yang ada, hasil wawancara, survey dan observasi yang dilakukan peneliti langsung. Untuk menunjang output yang dihasilkan reliable, pada tahapan ini diperkuat dengan data empiris dari studi literatur yang dilakukan penulis.

\section{Pengukuran Modul PMO}

Pengukuran didapatkan dari data yang dihimpun penulis berdasarkan kuesioner dan wawancara yang telah dilakukan. Pengukuran ini berdasarkan pengaruh peran yang terdapat pada aplikasi PMO dengan kinerja proyek yang telah berjalan maupun yang sedang berjalan. 


\section{Pengolahan Data}

Data yang telah di peroleh maka dilakukan analisa menggunakan uji faktor analisis dan pemaparan deskriptif. Tujuan dari pengolahan data adalah untuk menentukan variabel atau faktor dari penerapan PMO yang paling mempengaruhi kinerja proyek. Serta melihat korelasi diantara peran - peran PMO yang paling mempengaruhi kinerja proyek

\section{Pengambilan Kebijakan/Rekomendasi}

Setelah faktor didapat maka yang dari faktor tersebut akan menentukan guna pengambilan kebijakan kelanjutan dari penerapan PMO yang bermanfaat untuk percepatan proyek -proyek yang ada di lingkungan PLN.

\section{Hasil dan Pembahasan}

\section{Populasi dan Sample Penelitian}

Penelitian dilakukan mulai April minggu Pertama hingga bulan Juni minggu ketiga. Penyebaran data dilakukan dengan menggunakan email resmi perusahaan sehingga target sampling dapat tepat sasaran kepada pengguna PMO dalam hal ini admin aplikasi dan pelaksana atau koordinator proyek dilapangan. Dari populasi 54 koordinator proyek dan admin aplikasi system PMO. Peneliti mendapat responden sebanyak 50 yang mengisi kuesioner tetapi yang melakukan pengisia kuesioner secara valid terdapat 43 data. Selanjutnya data yang sudah valid secara kelengkapan pengisian dilakukan uji validitas dan uji reabilitas untuk menyatakan bahwa kuisoner tersebut sudah handal dan layak diproses lebih lanjut.

Kuesioner dikirimkan melalui email resmi perusahaan dengan target responden adalah pelaksana proyek di lapangan yang memiliki kewajiban untuk melaporkan progress proyek kedalam system PMO dan pengguna langsung PMO yang bertindak sebagai admin sistem PMO. Admin merupakan orang yang berkenaan langsung dengan system PMO dan menerima laporan dari pelaksanaan proyek dilapangan. Lingkup dari pelaksana proyek adalah proyek manager atau koordinator proyek. Dalam penelitian ini proyek yang kami angkat adalah proyek yang bernilai lebih dari 10 milyar dan merupakan proyek pembangunan infrastruktur ketenagalistrikan. 


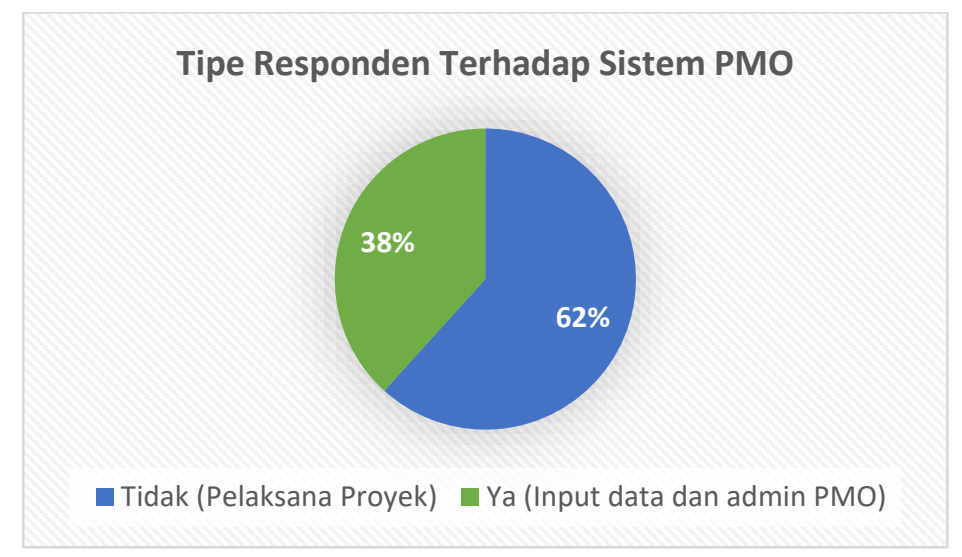

Gambar 1. Tipe Responden dalam Sistem PMO

Gambar 1 merupakan persentase dari responden berdasarkan tipe pekerjaannya. Seperti yang telah disebutkan diatas responden terbagi menjadi dua tipe yakniyang melaksanakan proyek dan responden yang menjadi admin. Persentase terbesar adalah pelasana dilapangan hal ini memang menggambarkan user yang lebih banyak menadi pelaksana dan admin yang berkenaan langsung dengan PMO memang sedikit jumlahnya.

\section{Uji Validitas dan Reliabilitas}

Dari hasil analisis dengan menggunakan program bantu statistik dengan hasil sesuai yang ada pada lampiran uji validitas dan uji reliabel dari tabel didapat angka croncbach alpha dengan ketentuan nilai 0.971 yang mana lebih besar dari nilai minimal yaitu 0.6 sehingga kuisoner tersebut dapat dikatakan reliabel dapar dilihat pada gambar 2 .

Sedangkan untuk uji validitas data dari lampiran tabel uji validitas didapat nilai $r$ hasil hitung program bantu melebihi $r$ tabel yang ditentukan jika nilai $\mathrm{N}=43$ didapat nilai $r$ yaitu 0.301 untuk taraf signifikan $5 \%$ hanya teradapat satu variabel yang dibawah nilai r tabel yaitu variabel Q17. 


\section{Scale: ALL VARIABLES}

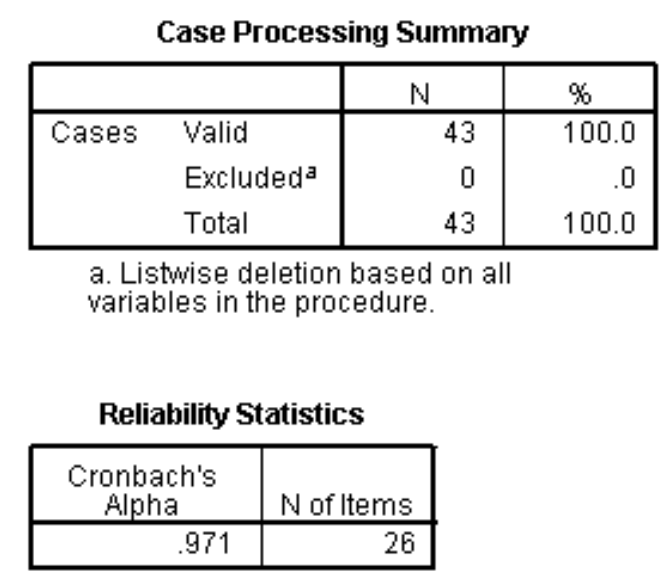

Gambar 2. Hasil Uji Reliabilitas

Dari uji analisa faktor terdapat beberapa data yang didapat yang pertama terlampir adalah data keterkaitan antar variabel bebas. Data dikatakan valid jika mendekati 0 dari hasil uji statistic determinant yang diperoleh adalah 0,0004 maka data dapat dipergunakan.

Tabel 1. Tabel KMO dan Barlett

\begin{tabular}{cc}
\hline Kaiser-Meyer-Olkin Measure of Sampling Adequacy & $\mathbf{0 . 6 4 8}$ \\
\hline Bartlett's Test of Sphericity Approx. Chi-Square & 954.533 \\
Df & 91.000 \\
Sig. & 0.000 \\
\hline
\end{tabular}

Setelah koefisien asumsi analisa faktor yang kedua adalah dengan melihat hasil Kaiser meyer olkin measure sampling (KMO) yang merupakan indeks pembanding antara koefisien korelasi dengan koefisien parsial. Nilai KMO dianggap mencukupi jika lebih dari 0.5 dan hasil penelitian tampak pada gambar diatas yakni 0.648, sehingga data dianggap memenuhi syarat. Dan data bartlett test 954.533 dengan signifikansi 0.000 memenuhi syarat karena niai signifikansi lebih kecil dari $0.05(5 \%)$.

Penilaian analisa faktor berikutnya dilihat dari tabel communalities pada tabel 2, data dapat di gunakan jika nilai komunalities lebih besar dari 0.5 jika nilai comunalities lebih kecil dari 0.5 variabel tersebut harus dikeluarkan dan perhitungan analisa faktor harus diulang dari awal. Untuk penelitian ini semua variabel memenuhi syarat 
Tabel 2. Communalities

Communalities
\begin{tabular}{|l|r|r|}
\hline & Initial & Extraction \\
\hline Q5 & 1.000 & 0.941 \\
Q6 & 1.000 & 0.810 \\
Q12 & 1.000 & 0.831 \\
Q13 & 1.000 & 0.864 \\
Q18 & 1.000 & 0.864 \\
Q19 & 1.000 & 0.405 \\
Q16 & 1.000 & 0.773 \\
Q17 & 1.000 & 0.806 \\
Q1 & 1.000 & 0.931 \\
Q2 & 1.000 & 0.789 \\
Q25 & 1.000 & 0.797 \\
Q26 & 1.000 & 0.847 \\
Q7 & 1.000 & 0.799 \\
Q8 & 1.000 & 0.872 \\
\hline
\end{tabular}

Extraction Method: Principal

Component Analysis.

Setelah beberapa pengujian data dengan menggunakan correlation matriks, $\mathrm{KMO}, \mathrm{MSA}$, dan communalities maka tahapan selanjutnya adalah pengelompokan data.

Tabel 3. Tabel Rotated Component

Rotated Component Matrix ${ }^{a}$

\begin{tabular}{|l|r|r|r|}
\hline & \multicolumn{3}{|c|}{ Component } \\
\cline { 2 - 4 } & 1 & \multicolumn{1}{|c|}{2} & \multicolumn{1}{l|}{3} \\
\hline Q5 & 0.779 & 0.498 & 0.296 \\
Q6 & 0.513 & 0.079 & 0.736 \\
Q12 & 0.329 & 0.865 & -0.08 \\
Q13 & 0.593 & 0.674 & 0.239 \\
Q18 & 0.537 & 0.675 & 0.247 \\
Q17 & 0.091 & 0.632 & 0.604 \\
Q1 & 0.108 & 0.067 & 0.889 \\
Q2 & 0.611 & 0.55 & 0.367 \\
Q25 & 0.542 & 0.496 & 0.5 \\
Q26 & 0.196 & 0.54 & 0.591 \\
Q7 & 0.857 & 0.292 & 0.163 \\
Q8 & 0.546 & 0.242 & 0.665 \\
\hline
\end{tabular}

Extraction Method: Principal Component

Analysis.

Rotation Method: Varimax with Kaiser Normalization. 
Dari tabel 3 dapat dilihat bahwa pembentuk faktor pertama terdiri dari beberapa variabel Q5, Q6, Q2, Q26, Q8 pembentuk faktor kedua terdiri dari Q13, Q11,Q8, dan kelompok ketiga hanya terdiri dari dua variabel Q17, Q7

\section{Pembahasan}

Tujuan awal dari sub bab pembahasan adalah menjawab hubungan antara penerapan system PMO dengan Kinerja proyek. Pada analisa diatas telah dideskripsikan hubungan antara faktor yang mempengaruhi kinerja proyek dan variabel-variabel pendukung dalam system PMO yang di wakilkan oleh variabel faktor 1, faktor 2 dan faktor 3.

a. Pembentuk Faktor 1

Tabel 4. Pembentuk Fakor Pertama

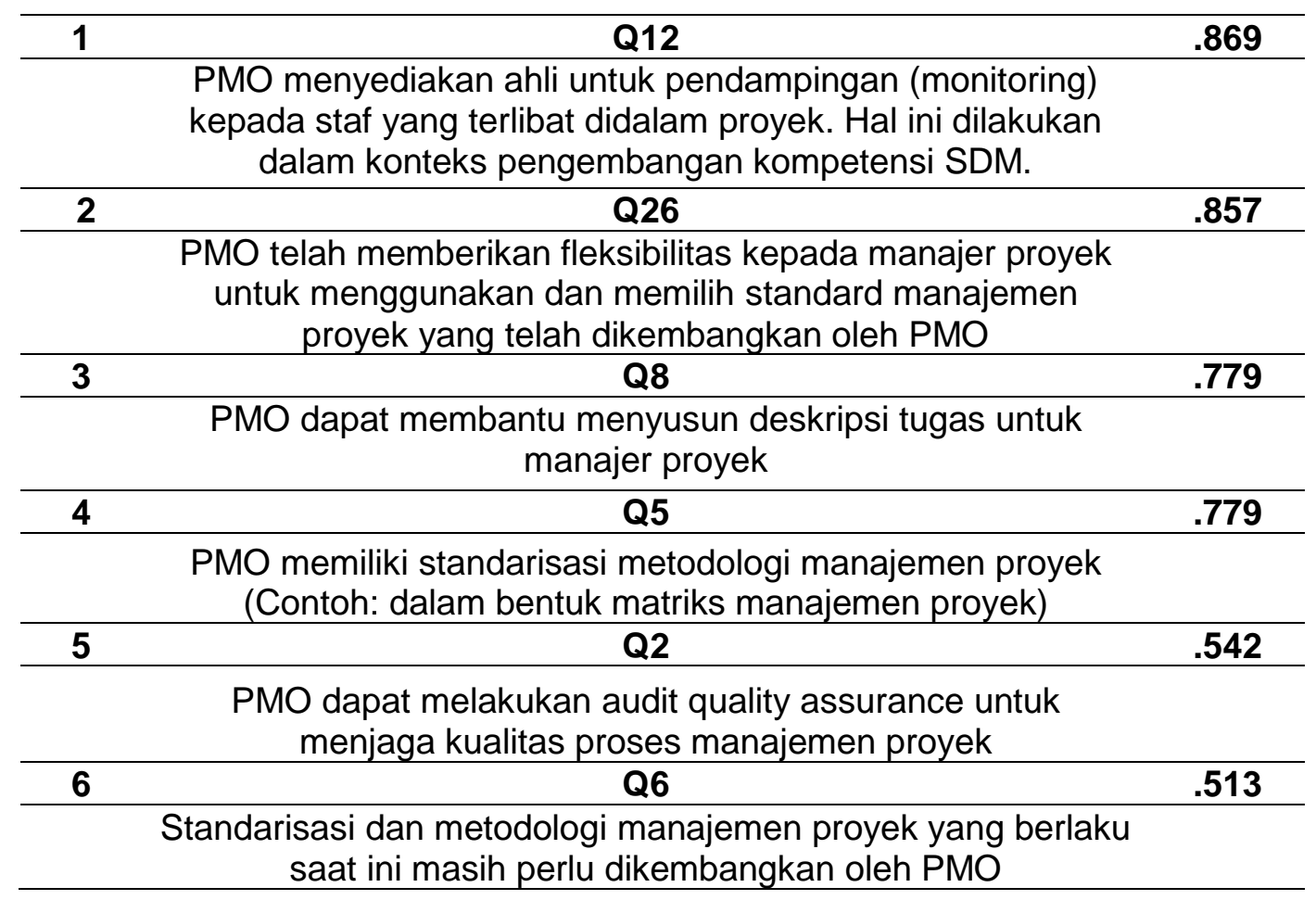

Jika dilihat tabel diatas pengelompokan variabel pada pembentukan faktor pertama berdasarkan dari point - point pertanyaanya yang merujuk pada penelitian yang dilakukan Crawford. Maka variabel - variabel tersebut termasuk dalam peran Proses, Metodologi, Standart sehingga dapat ditarik kesimpulan bahwa peran tersebut memiliki pengaruh terhadap kinerja proyek di PLN. Hal ini didukung juga oleh hasi penelitian Wells. yang diketahui dari 96 organisasi yang menerapkan standard dan metode manajamen proyek sebagai salah satu fungsi project management office membuktikan memiliki korelasi yang positif pada performa proyek yang dilaporkan. 
Disebut dalam penelitiannya yang termasuk ke dalam proses,standart, metodologi PMO yaitu :

1. Standarisasi Instruksi Kerja

2. Standarisasi Kriteria Evaluasi

3. Standarisasi Pengukuran Performa

4. Matriks dan standard Proyek Kerzner (2009) menyebutkan konsep standrisasi pada PMO antara lain

1. Standarisasi estimasi

2. Standarisasi perencanaan

3. Standarisasi Penjadwalan

4. Standarisasi Pengendalian

5. Standarisasi Pelaporan

6. Penyusunan data lesson learned

b. Pembentuk Faktor 2

Tabel 5. Pembentuk Fakor Kedua

\begin{tabular}{|c|c|c|}
\hline 1 & Q13 & .865 \\
\hline \multicolumn{3}{|c|}{$\begin{array}{l}\text { PMO telah membuat program transfer pengetahuan } \\
\text { (Knowledge transfer) mengenai proyek atau manajemen } \\
\text { proyek. }\end{array}$} \\
\hline 2 & Q18 & .675 \\
\hline \multicolumn{3}{|c|}{$\begin{array}{c}\text { PMO memiliki database kompetensi yang meliputi } \\
\text { kemampuan teknis, kapabilitas, spesifikasi, dan pengalaman } \\
\text { manajer proyek beserta tim proyek }\end{array}$} \\
\hline 3 & Q11 & .674 \\
\hline & $\begin{array}{l}\text { PMO memiliki program training untuk software manajemen } \\
\text { proyek (contoh: MS Project,Primavera, dan lainnya) kepada } \\
\text { tim manajemen proyek }\end{array}$ & \\
\hline
\end{tabular}

Pengelompokan variabel pembentuk faktor 2 berdasarkan point - point pertanyaan yang merujuk pada Crawford. Maka dapat disimpulkan pembentuk faktor yang kedua adalah peran SDM. PMO akan berperan terhadap pemilihan manajer proyek, pengembangan karir, pengumpulan database tentang manajer proyek terkait dengan kemampuan teknis serta penyusunan deksripsi tugas untuk manajer proyek. Crawford (2001) berpendapat fungsi dari manajer proyek sangat kuat mempengaruhi dan berdampak positif terhadap kinerja proyek. Salah satu alasannya yang dikemukan yaitu manajer proyek yang terbentuk dari respresentatif PMO akan lebih sejalan dan peduli terhadap penerapan PMO serta mengedepankan PMO terhadap kinerja proyek. Houssan (2011) menyatakan bahwa sebanyak 83\% responden setuju 
bahwa manajer proyek yang berada pada PMO mempunyai peran menambah nilai organisasi sehingga pengaruh SDM khususnya manajer proyek terhadap kinerja proyek memilik dampak positif.

c. Pembentuk Faktor 3

Tabel 6. Pembentuk Fakor Ketiga

1

Q17

.889

PMO memiliki standarisasi dalam penyediaan data acces dan level-nya kepada anggota tim proyek (IT governance policy)

2

Q7

.665

PMO dapat membantu menyusun program pengembangan karir manajer proyek berserta timnya

Untuk variabel yang ada pada faktor 3 menunjukan pada peran sarana berdasarkan dari point pertanyaan yang merujuk dari (Crawford, 2001). Walaupun terdapat poin dari peran SDM di faktor ke 3 ini akan tetapi peran SDM sudah terdapat pada pembentuk faktor kedua dan prosentase lebih kecil maka yang digunakan adalah peran sarana. Peran sarana disini terkait project support dan software tools. Menurut Dai (2004) menyebutkan bahwa sarana pendukung admnistrasi proyek semakin luas yang sejalan dengan jumlah dan jenis proyek yang ditangani. Beberapa bidang terkait dengan sarana pendukung ini seperti project management information system dan beberapa software pendukung lainnya dapat memberikan pengaruh positif terhadap kinerja proyek.

\section{Kesimpulan}

Berdasarkan hasil peneltian dan pengolahan data terhadap implementasi PMO pada di PLN untuk proyek infrastruktur ketenagalistrikan, maka dapat disimpulkan peran Project Management Office (PMO) yang berpengaruh pada implementasi PMO terhadap kinerja proyek infrastruktur ketenagalistrikan adalah Faktor proses, standar, metodologi, faktor SDM dan faktor sarana. Pengembangan produk customized.

\section{Saran}

Saran yang dapat diberikan untuk penelitian ini adalah penelitian selanjutnya dapat menciptakan dan mengembangkan variabel yang baru sehingga implementasi dari PMO dapat lebih detail penggambarannya. 


\section{Daftar Referensi}

Andersen, B., Henriksen B., \& Aarseh, W. (2007). Benchmarking of project management office establishment: extracting best practice. Journal of Management in Engineering, Vol. 23, No. 2, pp. 97-104.

Crawford, J. K. 2001. The Strategic Project Office. PM Solutions White Paper.

Institute, P. M.2013. A Guide to The Project Management Body Of Knowledge . Pennsylvania: Project Management Institute.

Kuen, C. W. 2009. Critical Factors Influencing the Project Success Amongst Manufacturing Companies in Malaysian. African Journal of Business Management, 16-27.

Perdana, B. P.2013 Pengaruh Peran Project Management Office (PMO) pada tingkatan Multiple Project terhadap Kinerja Proyek EPC. Jakarta: Universitas Indonesia.

Sebayang, N. 2012. detikfinance. Retrieved April Minggu, 2017, from http://finance.detik.com/energi/2075437/pln-siapkan-rp-45-miliar-untuk-databaseproyek

Simanjuntak, Payaman J. 2005. Manajemen dan Evaluasi Kinerja. Jakarta: FE UI.

Wells, D. \&. 2004. An Explorationn of Project Management Office Features and Their RelationShip to Project Performance. International Journal of Project Management, 523-532. 